\title{
Sustainability Product Portfolio: A Review
}

\author{
Carolina Villamil ${ }^{1}$, Sophie I. Hallstedt ${ }^{2}$
}

\begin{abstract}
Many companies have identified the importance of sustainable innovation for long-term competitiveness and recognition but face difficulties in translating sustainability strategies into practical action. Some companies have shown an interest to include sustainability dimensions into their product portfolio, which can be an efficient way to communicate the sustainability performance of the products internally and externally and even speed up the development of more sustainable solutions. Our research aims to determine how a sustainability portfolio can be defined and how to assess portfolios from a sustainability perspective. A systematic literature review on sustainability product portfolio was conducted. The results indicated that a general portfolio setting follows a selection criteria and the company's strategies, which usually are based on management elements, e.g., time, cost, risk, quality, etc., leaving behind sustainability variables. Most of the tools used for evaluation criteria miss the holistic view. The companies could benefit from a systematic approach to implementing sustainability into their product portfolio. The findings were connected with a previous study to evaluate a sustainability assessment approach used for a technology portfolio. For future work, a descriptive study will complement an understanding on how to guide companies to shape their sustainability product portfolios.
\end{abstract}

Keywords: Sustainable product development, sustainability porffolio, product planning, portfolio management, product portfolio

\section{Introduction}

Generally, companies have a portfolio of products, services, processes and/or technologies with specific characteristics, and they arrange the portfolios from the early phases of the product development process, i.e., in the product planning phase (Ulrich \& Eppinger, 2012). To achieve a balanced product portfolio, a company selects from several project alternatives. To have a good set of projects it is important to implement selection criteria: "Project portfolio selection is an activity where early decisions affecting the environmental performance of a product are made" (Ölundh \& Ritzen, 2004). In many cases, the selection criteria are shaped by management elements such as cost, time, effectiveness, quality etc., leaving behind sustainability variables. Companies have shown an interest to include the environmental, social and economic perspective into their company product portfolio (Silvius \& Schipper, 2015). However, there are few studies focused on the integration of sustainability in project management (Martens \& Carvalho, 2017). Previous research has shown that including sustainability into the project management process will give a holistic perspective, generate solutions for short and long-term perspectives, open up for collaboration and agreements between stakeholders, and result in other advantages that can improve the performance of the projects (Økland, 2015). The purpose of this paper is to explore the state of the art of 
sustainability product portfolio, and determine the conceptual framework, challenges, tools, and many other elements that are relevant for sustainability integration and implementation. First some theoretical concepts will be presented, followed by the research methodology, results, discussion and conclusions.

\subsection{Product Portfolio - Theoretical Concepts}

Usually when a company plans a new product, process or/and technology, a project is created, which will be part of the company's portfolio. A project is defined as: "a temporary group activity designed to produce a unique product, service or result" (PMI, 2013). Cooper et al. (2001) mentioned that in Product Portfolio Management (PPM): "existing projects may be accelerated, killed, or deprioritized and resources are allocated and reallocated to the active projects". A product portfolio is defined by the characteristics of the product, which determine product families according to their relationship in different fields e.g., market, use, target, technology, etc. (Mansoornejad et al., 2010). One of the goals of PPM is to have a balanced portfolio, which will consider variables such as: value, minimal risk, diversity, flexibility, long term and short-term perspective. Success in the project management is related to the three main aspects known as the "Iron triangle" (Silvius \& Schipper, 2015): scope, time and cost. (Martens \& Carvalho, 2016). Product planning is the early phase of the product development process; it has five stages to manage projects and portfolio. These are: i) identify opportunities; ii) evaluate and prioritize projects; iii) allocate resources and plan timing; iv) complete pre-project planning, where projects are aligned with the requirements of the company and v) evaluate several variables using the competitive strategy e.g., meet the market and technology requirements (Ulrich \& Eppinger, 2012).

\subsection{Sustainability - Theoretical Concepts}

Sustainable development has been defined as: “...the development that meets the needs of the present without compromising the ability of future generations to meet their own needs" (World Commission on Environment and Development, 1987). The triple bottom line TBL considers three dimensions of sustainability: environmental, social and economic sustainability (Elkington, 2002). The Framework for Strategic Sustainable Development (FSSD) is a holistic model used to move society towards sustainability, and this framework uses backcasting as a pillar, which means to set a vision for the desired future as a compass to plan and take actions (Broman \& Robèrt, 2017). The FSSD is founded on eight sustainability principles, which are: "in a sustainable society, nature is not subject to systematically increasing (1) ...concentrations of substances from the Earth's crust, (2) ...concentrations of substances produced by society, (3) ... degradations by physical means, and, in that society people are not subject to structural obstacles to (4) bealth, (5) influence, (6) competence, (7) impartiality, and, (8) meaning-making" (Broman \& Robèrt, 2017). Sustainability has been included in the design of products with the concept known as eco-design, defined as: "Sustainable solutions are products, services, hybrids or system changes that minimize negative and maximize positive sustainability impacts - economic, environmental, social and ethical - throughout and beyond the life-cycle of existing products or solutions, while fulfilling acceptable societal demands/needs" (Charter \& Tischner, 2001). According to Hallstedt and Isaksson (2017), sustainable product 
development has a "strategic sustainability perspective" based on life-cycle thinking and is implemented in the early stages of the innovation process.

\section{Methodology}

A systematic literature review was planned and developed following the guidance of the research methodology proposed by Blessing and Chakrabarti (2009). First, an initial review on the sustainability portfolio concept was performed to identify key words, and the scope of the research. In the initial review, only eight papers were found in the specific area. The query was broadened and a new key words list was determined including: sustainab* product - service, sustainab* product portfolio, ecodesign of product portfolio, frameworks for sustainab* product portfolio, assessments for sustainab* product portfolio, guidelines for sustainab* product portfolio, sustainab* criteria product portfolio, design of sustainab* product portfolio, innovation of sustainab* product portfolio, etc. The query used is presented in Figure 1. The data base used was SCOPUS and the search was limited to 2000 to 2017. First, the references were assessed by title, abstract, and conclusions, and the most relevant ones were selected and read. A snowballing method (Wohlin, 2014) was used to add relevant publications. The literature review was not restricted to journal and conference articles, it also included company reports to obtain knowledge and expertise from the industry. The final list of 48 references was organized, classified and analyzed. The findings were related to a previous study, made by the authors, on the sustainability assessment of Additive Manufacturing (AM) technologies, to identify which key factors define a sustainability technology portfolio. The methodology is an iterative process and it is presented in Figure 2.

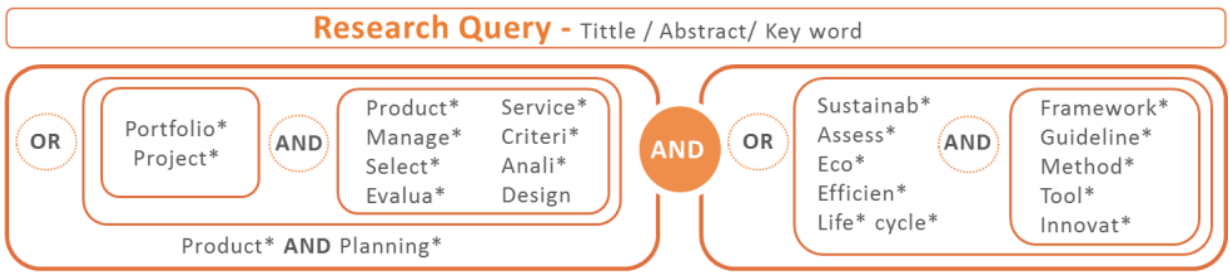

Figure 1. Research query

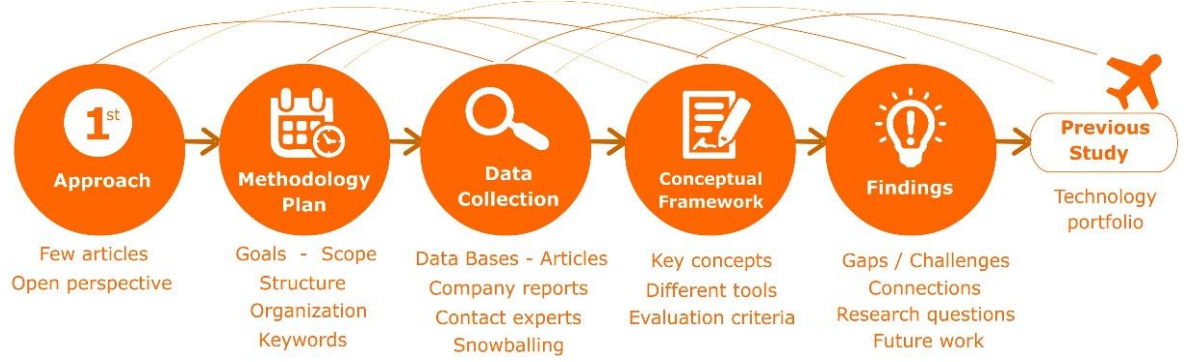

Figure 2. Literature review methodology, designed by the authors and inspired by Blessing and Chakrabarti (2009). 


\section{Results and Discussion}

The purpose was to clarify the conceptual framework, challenges, tools, and other relevant variables to define a sustainability product portfolio. Table 1 presents a summary of the key facts and Table 2 lists the key facts identified in the literature review. These facts are classified as follows: the reference approach (e.g., academic research, company reports, project planning), selection criteria (e.g., multicriteria, mix of tools, balanced portfolio), management variables (e.g., business unit, cost, resources, quality, risk), and sustainability variables (e.g., life-cycle perspective, triple bottom line, eco-label, social perspective). These facts will be elaborated in detail in the below sections.

\subsection{Defining the Portfolio Concept}

There is not a concrete definition for a sustainability product portfolio in the literature review. Generally, portfolio is defined by portfolio management and project management (Cooper et al. 2001). In product planning, the product portfolio is managed and projects are evaluated and planned (Ulrich \& Eppinger, 2012). Four references mentioned the product planning concept. In a portfolio, the elements inside are related and have similar characteristics that cluster them into portfolios by using, e.g., a marketdriven analysis (Mansoornejad et al., 2010). Including sustainability into project management and portfolio management can offer many advantages seen from environmental, economic and social perspectives (Brones et al., 2014). Based on the literature review, a summary of concepts to be used to define a sustainability product portfolio is presented in Figure 3. Some key factors were proposed to define the sustainability product portfolio based on the literature review results, and these are listed in Table 3.

Table 1. Summary of the key facts of the systematic literature review

\begin{tabular}{|c|c|c|c|c|c|c|c|}
\hline $\begin{array}{l}\text { Reference } \\
\text { approach }\end{array}$ & Total & Selection criteria & Total & $\begin{array}{l}\text { Management } \\
\text { variables }\end{array}$ & Total & Sustainability & Total \\
\hline $\begin{array}{l}\text { Academic } \\
\text { research } \\
\text { Case study } \\
\text { research } \\
\text { Company report } \\
\text { Portfolio } \\
\text { management } \\
\text { Project } \\
\text { management } \\
\text { Product planning } \\
\text { Strategy of the } \\
\text { company } \\
\text { Early stages }\end{array}$ & $\begin{array}{c}21 \\
\\
6 \\
27 \\
\\
29 \\
\\
4 \\
23 \\
14\end{array}$ & $\begin{array}{l}\text { Multicriteria } \\
\text { Based on tools } \\
\text { Mix of tools } \\
\text { Score criteria } \\
\text { Balanced portfolio } \\
\text { Several steps } \\
\text { Use a matrix } \\
\text { Graphic } \\
\text { Representation }\end{array}$ & $\begin{array}{c}7 \\
35 \\
20 \\
15 \\
11 \\
25 \\
15 \\
26\end{array}$ & $\begin{array}{l}\text { BU - Business Unit } \\
\text { ROI - Return of } \\
\text { Investment } \\
\text { Cost } \\
\text { Resources } \\
\text { Time } \\
\text { Quality } \\
\text { Risk } \\
\text { KPI - Key } \\
\text { Performance Ind. } \\
\text { Value } \\
\text { Stakeholder analysis } \\
\text { Value chain } \\
\text { management }\end{array}$ & $\begin{array}{c}12 \\
6 \\
\\
34 \\
24 \\
26 \\
19 \\
26 \\
8 \\
\\
\\
20 \\
33 \\
18\end{array}$ & $\begin{array}{l}\text { Life cycle } \\
\text { perspective } \\
\text { Holistic view } \\
\text { TBL - Triple } \\
\text { Bottom Line } \\
\text { GRI - Global Rep. } \\
\text { Initiative } \\
\text { Eco- label } \\
\text { CO2 - Carbon foot } \\
\text { print } \\
\text { Energy } \\
\text { consumption } \\
\text { Social perspective } \\
\text { CSR - Corp. Social } \\
\text { Respon. } \\
\text { Eco-design } \\
\text { Eco-efficiency }\end{array}$ & $\begin{array}{l}25 \\
9 \\
11 \\
13\end{array}$ \\
\hline
\end{tabular}


Table 2. Summary of the key facts of reviewed references
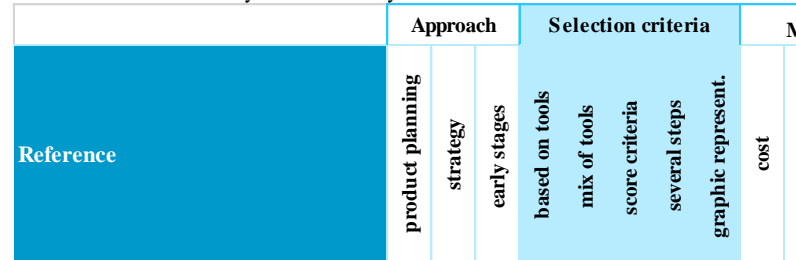

Management variables

Sustainability

Ali et al., 2016

Brones et al., 2017

Brones \& Carvalho, 2015

Brones et al., 2014

Brones et al., 2013

Brook \& Pagnanelli, 2014

Buchert et al., 2014

Carvalho \& Rabechini, 2017

Cluzel et al., 2016

Damghani \& Nezhad, 2013

Epstein \& Wisner, 2001

Figge et al., 2002

Gareis et al., 2010

Gmelin \& Seuring, 2014

Grießhammer et al., 2010

Hope \& Moehler, 2014

Ihuah et al., 2014

Janssen \& Stuart, 2010

Ketola, 2010

Kivilä et al., 2017

Kohl, 2016

Labuschagne \& Brent, 2005

Mansoornejad et al., 2010

Marcelino-Sádaba et al., 2015

Martens \& Carvalho, 2017

Martens \& Carvalho, 2016

Meinrenken et al., 2012

Pimentel et al., 2016

Sánchez, 2015

Silvius et al., 2017

Silvius \& Schipper, 2015

Silvius \& Schipper, 2014

Schmidt et al., 2004

Trapp \& Sarkis, 2016

Uhlman \& Saling, 2010

Ulrich \& Eppinger, 2012

Vandaele \& Decouttere, 2013

Wever et al., 2008

Vliex, 2013

Zvezdov \& Hack, 2016

Økland, 2015

Ölundh \& Ritzén, 2004
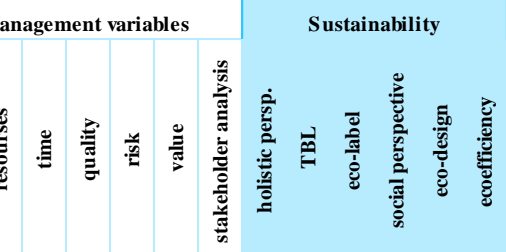

Companv Reports

Akzonobel, 2016

BASF, 2015

Clariant \& CSCP, 2015

Henkel, 2014

Lanxess, 2016

Solvay, 2010

TOTAL 


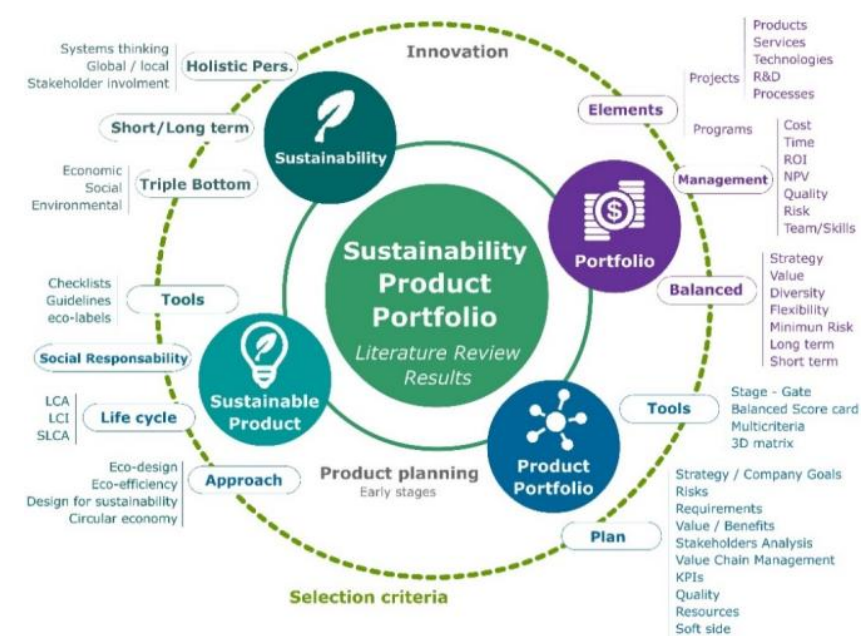

Figure 3. Literature review concepts to define a sustainability product portfolio.

Table 3. Key factors for the definition of a sustainability product portfolio

\begin{tabular}{|l|l|}
\hline Key factors & Reference \\
\hline - Integration of sustainability in all the stages and elements & (Mansoornejad el al 2010) \\
- Holistic view - system thinking & (Brones et al, 2017) \\
- Stakeholder analysis and Supply chain management (identify all the connections) & (Sánchez, 2015) \\
- Early stage procedures - Product planning & (Ulrich \& Eppinger, 2012) \\
- Alignment with the company goals and strategy & (Cluzel et al. 2016) \\
- Include Risk management, Product value and Product Requirements in the process & (Kohl, 2016) \\
- Stage - Gate Model and multicriteria selection models & (Ölundh \& Ritzén, 2004) \\
- Innovation - new approaches (circular design, biomimicry, PSS, shared economy, etc.) & (Hallstedt \& Isaksson, 2017) \\
- Complete assessment of the product life cycle & (Ulrich \& Eppinger, 2012) \\
\hline
\end{tabular}

\subsection{Early Stages of the Product Development Process and the Levels of the Organization}

Fourteen references mentioned that sustainability variables can be implemented in the early stages or the fuzzy front end of the product innovation process (Wever et al. 2008). Instead of inserting them in the middle or the end of the process, when few changes can be made. Many projects are shaped in the ideation stage, where sustainability facts should be included (Ölundh \& Ritzen, 2004). Usually, the required data to include sustainability is not available in the early stages (Marcelino-Sádaba et al., 2015). Portfolio setting is part of the strategic level (Hope \& Moehler, 2014), and strategy means longterm decisions (Pimentel et al. 2016). 23 references mentioned that environmental decisions should be implemented at the strategic level, as part of the goals and strategy of the company (Ölundh \& Ritzen, 2004). It is crucial, however, to include sustainability at all levels of the organization (Hope \& Moehler, 2014).

\subsection{Tools and the Evaluation Criteria}

The tools used to select the product portfolio components (projects, products, technologies, etc.) are related to portfolio management, project management, product development, product planning, sustainability and eco-design. 25 references used several steps in the selection criteria. Usually, the first steps evaluate future projects and the final 
stage defines a balanced portfolio with a set of projects, which fulfils the selection process requirements. Certain models used a combination of tools, e.g., portfolio management cycles combined with GRI indicators (Vliex, 2013), the opportunitystrength matrix combined with the eco-design matrix (Wever et al., 2008). In Table 1, in the selection criteria, 35 references mentioned to be based on tools, etc., 20 mentioned the need to combine several tools, 15 used matrixes and 7 used multicriteria. The most used tools are presented in Table 4. The Balance Score Card (BSC) and the Stage-Gate model are the most used tools in the management and product development field, used by 8 and 6 references respectively. Life Cycle Assessment (LCA) is the most used tool to analyze the complete life cycle of a product, from raw material extraction to the end of life, identifying the environmental impacts in each stage of the cycle (ISO, 2006). 15 references used LCA. Ten knowledge areas for project definition are proposed, such as: "project integration management, scope, time, cost, quality, human resource, communications, risk, procurement management and stakeholder management" (PMI, 2013). For the evaluation process, cost is the most used variable (34 times) followed by risk (26), time (26) and resources (24). The definition of the product portfolio is linked to the strategy and goals of the company (Kohl, 2016). 23 references mentioned the importance to include sustainability in the strategy of the company, ensuring sustainability awareness from the early stages of the product development process (Brones \& Carvalho, 2015). 30 references considered the pillars of sustainability or TBL: social, environmental and economic sustainability (planet, people and profit).

Table 4. Most used tools for portfolio selection and evaluation

\begin{tabular}{|c|c|c|}
\hline $\begin{array}{l}\text { Management / } \\
\text { product dev. tool }\end{array}$ & \# & References \\
\hline $\begin{array}{l}\text { Balance Score Card } \\
\text { BSC }\end{array}$ & 8 & $\begin{array}{l}\text { (Akzonobel, 2016) (Damghani \& Nezhad, 2013) (Epstein \& Wisner, 2001) (Figge et al., } \\
\text { 2002) (Kohl, 2016) (Sánchez, 2015) (Solvay, 2010) (Ölundh \& Ritzen, 2004) }\end{array}$ \\
\hline Stage-Gate Model & 6 & $\begin{array}{l}\text { (Brones \& Carvalho, 2015) (Clariant \& CSCP, 2015) (Henkel, 2014) (Solvay, 2010) } \\
\text { (Vandaele \& Decouttere, 2013) (Ölundh \& Ritzen, 2004) }\end{array}$ \\
\hline Multi-criteria & 4 & $\begin{array}{l}\text { (Brook \& Pagnanelli, 2014) (Cluzel et al., 2016) (Janssen \& Stuart, 2010) (Pimentel et al., } \\
\text { 2016) }\end{array}$ \\
\hline Stakeholder analysis & 4 & $\begin{array}{l}\text { (Sánchez, 2015) (Silvius \& Schipper, 2015) (Martens \& Carvalho, 2017) (Carvalho \& } \\
\text { Rabechini, 2017) }\end{array}$ \\
\hline $\begin{array}{l}\text { Data Envelopment } \\
\text { Analysis DEA }\end{array}$ & 2 & (Vandaele \& Decouttere, 2013) (Sánchez, 2015) \\
\hline $\begin{array}{l}\text { Sustainability } \\
\text { perspective tool }\end{array}$ & \# & References \\
\hline $\begin{array}{l}\text { Life cycle } \\
\text { assessment (LCA) }\end{array}$ & 15 & $\begin{array}{l}\text { (Akzonobel, 2016) (BASF, 2015) (Buchert et al., 2014) (Cluzel et al., 2016) (Grießhammer } \\
\text { et al., 2010) (Henkel, 2014) (Janssen \& Stuart, 2010) (Mansoornejad et al., 2010) } \\
\text { (Meinrenken et al., 2012) (Pimentel et al., 2016) (Sánchez, 2015) (Schmidt et al., 2004) } \\
\text { (Solvay, 2010) (Uhlman \& Saling, 2010) (Zvezdov \& Hack, 2016) }\end{array}$ \\
\hline $\begin{array}{l}\text { Eco-Efficiency } \\
\text { Analysis }\end{array}$ & 4 & (BASF, 2015) (Grießhammer et al., 2010) (Schmidt et al., 2004) (Uhlman \& Saling, 2010) \\
\hline Social LCA & 2 & (Pimentel et al., 2016) (Grießhammer et al., 2010) \\
\hline \multicolumn{3}{|c|}{ Other Sustainability perspective tools } \\
\hline $\begin{array}{l}\text { Corporate Responsi } \\
\text { design matrix (Wev } \\
\text { (Ölundh \& Ritzen, }\end{array}$ & & $\begin{array}{l}\text { ortfolio Matrix (Ketola, 2010), Eco-Value Analysis (Buchert et al., 2014), Eco- } \\
\text { 2008), Eco-design wheel (Cluzel et al., 2016), Product development Check lists } \\
\text { Ppportunity-strength matrix (Wever et al., 2008) }\end{array}$ \\
\hline
\end{tabular}

\subsection{Challenges}

There are challenges to implement sustainability into project management, such 
as: lack of holistic perspective, practical use, no connection of local and global perspectives, etc. (Økland, 2015). 13 references have mentioned that it is crucial to have a holistic view and a system thinking approach in the integration of project management and sustainability (Silvius \& Schipper, 2014). 25 references mentioned the importance of analyzing the complete product life cycle. Some companies have focused only on reducing the carbon footprint (Zvezdov \& Hack, 2016). The results show that 11 references used an eco-design approach, 13 used eco-efficiency and 9 used Global Reporting Initiative (GRI) as evaluation criteria. For some researchers, eco-design tools limit the innovation process (Cluzel et al., 2016). The LCA only focuses on current impacts and does not offer guidance for its implementation in the early stages of the innovation process. In contrast other approaches, such as the FSSD can provide support by including a backcasting approach, a complete system perspective of the process, and add a complete socio-ecological perspective (Broman \& Robèrt, 2017). Hallstedt and Isaksson (2017) proposed a systematic approach that takes into account the life-cycle thinking in the sustainability implementation. Some tools used to shape a company portfolio have focused mainly on the management and financial facts, leaving sustainability behind. Some companies identified the need to apply sustainability into project management but putting it into practice is challenging (Martens \& Carvalho, 2016). Some challenges to introduce sustainability are due to profits, resources, training, cost, resources, quality, deadlines and risks (Brones et al., 2014). Flexibility (Mansoornejad et al., 2010) and resilience (Martens \& Carvalho, 2017) are key terms in the development of a sustainability product portfolio.

\subsection{Social Sustainability and Portfolio}

Social perspective and corporate responsibility are key factors in portfolio management (Ketola, 2010). 25 references have mentioned the importance of the social perspective in the company portfolio. The social dimension is not a big concern when sustainability is applied to project management (Martens \& Carvalho, 2016). There is a lack of active participation of the involved stakeholders, and there is a need of project managers that know about sustainability issues, and therefore special training might be needed regarding these aspects (Ali et al., 2016). 17 references mentioned the importance to enforce sustainability capabilities of the portfolio definition team (Silvius \& Schipper, 2014). For the effective sustainability performance, it is indispensable to engage stakeholders to participate actively (Kohl, 2016). 33 references mentioned the importance to use stakeholder analysis (Sánchez, 2015) and 18 mentioned value chain management (Carvalho \& Rabechini, 2017). There is a need to manage the supply chain with a sustainability perspective in order to have sustainability portfolios (Trapp \& Sarkis, 2016). Brones and Carvalho (2015) suggested to include communication and collaboration in the implementation of the social sustainability perspective.

\subsection{Communication}

Some researches and practitioners have developed communication tools that are easy to use to by the companies. 15 refences have used a score criteria with numbers (from zero to five) or with colours, e.g., the "traffic light" system, where green has the best sustainability performance and balance in terms of cost, time, risk, value and 
resources and red indicates low performance, sustainable negative impacts, high riskiness, or low value to the company (Clariant \& CSCP, 2015). 26 references used graphic elements to illustrate the selection criteria and classification using maps, matrices, etc., e.g., the three-dimensional analysis SEEcube - BASF (Schmidt et al., 2004) and the SPM heat map matrix (Solvay, 2010). Some companies have developed their own ecolabels for sustainable products that are part of the company portfolio, e.g., "ecopremium solutions" (AkzoNobel, 2016), "Henkel Sustainability\#Master ${ }^{\circledR}$ " (Henkel, 2014), and "EcoTain label" (Clariant \& CSCP, 2015).

Table 5. Key factors for sustainability technology portfolio

\begin{tabular}{|c|c|}
\hline Key factors & hnology portfolio focused on AM \\
\hline $\begin{array}{l}\text { - Integration of sustainability in all the stages and } \\
\text { elements } \\
\text { - Holistic view - system thinking } \\
\text { - Stakeholder analysis and Supply chain management } \\
\text { - Early stage procedures - Product planning } \\
\text { - Alignment with the company goals and strategy } \\
\text { - Include Risk management, Product value and } \\
\text { Product Requirements } \\
\text { - Stage - Gate Model and multicriteria selection } \\
\text { models } \\
\text { - Innovation - new approaches (biomimicry, etc.) } \\
\text { - Complete assessment of the product life cycle }\end{array}$ & $\begin{array}{l}\text { Improve buy to fly ratio - Reduce the amount of waste } \\
\text { Repair airplane parts - Increment the product life } \\
\text { Collaboration with stakeholders and improvement of } \\
\text { materials, processes, etc. } \\
\text { Choose the best sustainable alternatives from early stages } \\
\text { Improve knowledge, safety, competitiveness, awareness, etc. } \\
\text { Improve the component characteristics, processes, reduce } \\
\text { emission, waste, etc. } \\
\text { Introduce effective models to speed out the process } \\
\text { The Freedom of design (hive shape or organic form) reduce } \\
\text { weight and processes } \\
\text { Reduce waste and increment the product life and } \\
\text { performance }\end{array}$ \\
\hline
\end{tabular}

\subsection{Possible Application in a Sustainability Technology Portfolio}

In a product portfolio, a company may offer products, services, technologies and operations. In a previous study of an AM technology portfolio, a sustainability assessment showed several opportunities and challenges with AM technologies (Villamil et al., 2018). The purpose of relating with this case is to understand how companies shape their sustainability technology portfolio. The case comes from the aerospace industry that uses AM technologies and that includes these technologies in their product portfolio. The benefits with AM are, for example, the increase of the effectiveness of the manufacturing processes, and the reduction of the usage of raw material. Traditional manufacturing removes almost 87 percent of the weight from the original material piece to manufacture a metal component (Paris et al., 2016), the removed material turns into scrap. AM has a low range of scrap comparing with traditional technologies, this is a positive aspect in terms of cost and sustainability. Based on the key factors for the definition of a sustainability product portfolio presented in Table 3, Table 5 presents the key factors for the definition of a sustainability technology portfolio focus on AM.

\section{Conclusions}

Sustainability product portfolio is about sustainability considerations into product portfolio development. A company portfolio is a set of programs and projects and it is related completely with the business goals and the strategy of the organization. That means that companies introducing sustainability into their portfolio guarantee to have more sustainable products, services, processes or technologies.

Portfolio components are, usually, evaluated from a management perspective and 
sustainability has a small role in the evaluation criteria. The implementation of sustainability into the product portfolio should be focused on the environmental, social and economic sustainability variables, introducing these in the complete process from the early stage of the innovation process and integrating them with other elements of the portfolio evaluation criteria.

The evaluation criteria should be applied in the complete life cycle of the product and/or service with a systems thinking perspective, including in the process the stakeholders' participation, the arranging of a competent team, the management of a correct supply chain and other factors.

For the portfolio selection criteria there are multiple methods, frameworks, guidelines, strategies, etc., that have been used or adapted. The most used tools for guiding the selection of the elements that will be part of the portfolio are the BSC, Stage-Gate model and LCA.

There is a gap between portfolio management and sustainability implementation, and for that reason some companies have developed their own tools to include sustainability in their portfolio.

In future work, a descriptive study of manufacturing companies will be conducted, to determine the sustainability product portfolios from the company perspective. This will support the understanding of how companies could implement sustainability in their product portfolio in a practical and effective way. Afterwards, to create a method to implement sustainability in the early stage of the innovation process.

\section{Acknowledgements}

Financial support from the Knowledge Foundation and Vinnova in Sweden is gratefully acknowledged. Sincere thanks to the industrial research partner.

\section{References}

Ali, F., Boks, C., \& Bey, N. (2016). Design for Sustainability and Project Management Literature - A Review. Procedia CIRP, 48, 28-33. https://doi.org/10.1016/j.procir.2016.04.185

Akzonobel. (2016). Company Report. Retrieved March 08, 2018, from http://report.akzonobel.com/2016/ar/

BASF. (2015). Global Compact International Yearbook. Retrieved March 02, 2018, from https://www.basf.com/ en/company/sustainability/whats-new/sustainability-news/2015/globalcompact-international-yearbook.html

Blessing, L. T., \& Chakrabarti, A. (2009). DRM, a design research methodology. London: Springer.

Broman, G.I. \& Robèrt, K.-H. (2017). A framework for strategic sustainable development, Journal of Cleaner Production, 140, 17-31. Doi: 10.1016/j.jclepro.2015.10.121

Brones, F., Carvalho, M., \& Zancul, E. de S. (2017). Reviews, action and learning on change management for ecodesign transition. Journal of Cleaner Production, 142, 8-22. https://doi.org/10.1016/j.jclepro.2016.09.009

Brones, F., \& Carvalho, M. (2015). From 50 to 1: integrating literature toward a systemic ecodesign model. Journal of Cleaner Production, 96, 44-57. https://doi.org/10.1016/j.jclepro.2014.07.036

Brones, F., Carvalho, M., \& Zancul, S. (2014). Ecodesign in project management: a missing link for the integration of sustainability in product development? Journal of Cleaner Production, 80, 106-118. https://doi.org/10.1016/j.jclepro.2014.05.088

Brones, F., Carvalho, M., \& Salerno M. (2013) Environmental perspective into new products, portfolio: a challenge for the effectiveness of Ecodesign. Conference: Euroma - European Operations Management 
Association. Retrieved March 06, 2018, from https://www.researchgate.net/publication/261175770 Brook, J. W., \& Pagnanelli, F. (2014). Integrating sustainability into innovation project portfolio management - A strategic perspective. Journal of Engineering and Technology Management, 34, 46-62. https://doi.org/10.1016/j.jengtecman.2013.11.004

Buchert, T., Kaluza, A., Halstenberg, F. A., Lindow, K., Hayka, H., \& Stark, R. (2014). Enabling Product Development Engineers to Select and Combine Methods for Sustainable Design. Procedia CIRP, 15, 413-418. https://doi.org/10.1016/j.procir.2014.06.025

Carvalho, M. M., \& Rabechini, R. (2017). Can project sustainability management impact project success? An empirical study applying a contingent approach. International Journal of Project Management, 35(6), 1120-1132. https://doi.org/10.1016/j.ijproman.2017.02.018

Charter, M., \& Tischner, U., (2001). Sustainable Solutions, Developing Products and Services for the Future. Greenleaf Publishing, Sheffield.

Clariant \& CSCP. (2015). Developing Tools for Sustainable Product Portfolio Management - The Sustainability Clariant Portfolio Value Program Clariant and CSCP. Company Report. Retrieved March 02, 2018, from https://www.scp-centre.org/publications/developing-tools-sustainableproduct-portfolio-management/

Cluzel, F., Yannou, B., Millet, D., \& Leroy, Y. (2016). Eco-ideation and eco-selection of R\&D projects portfolio in complex systems industries. Journal of Cleaner Production, 112, 4329-4343.

Cooper, R., Edgett, S., \& Kleinschmidt, E. (2001): Chapter 1 - The Quest for the Right Portfolio Management Process. Portfolio Management for New Products. (2nd Ed.). Perseus Books Group, Reading.

Damghani, K., \& Nezhad, S. (2013). Strategic framework for sustainable project portfolio selection and evaluation. Int. J. of Sustainable Strategic Management, 4(1), 66. https://doi.org/10.1504/IJSSM.2013.056391

Elkington, J. (2002). Cannibals with forks: The triple bottom line of 21st century business. Oxford: Capstone Epstein, M. J., \& Wisner, P. S. (2001). Using a Balanced Scorecard to Implement Sustainability. Environmental Quality Management, 11(2), 1-10. https://doi.org/10.1002/tqem.1300

Figge, F., Hahn, T., Schaltegger, S., \& Wagner, M. (2002). The Sustainability Balanced Scorecard - linking sustainability management to business strategy. Business Strategy and the Environment, 11(5), 269-284. https://doi.org/10.1002/bse.339

Gareis, R., Huemann, M., \& Martinuzzi, A. (2010). Relating sustainable development and project management: a conceptual model. PMI® Research Conference. Washington, DC. Newtown Square, PA.

Gmelin, H., \& Seuring, S. (2014). Achieving sustainable new product development by integrating product life-cycle management capabilities. Int. J. of Production Economics, 154, 166-177. doi:10.1016/j.ijpe.2014.04.023

Grießhammer R., Bleher D., Dehoust G., Gensch C., Havers K., Hochfeld C., Groß R., Möller M., Seum S. (2010). PROSA - Product Sustainability Assessment Guideline. Öko-Inst.e.V. - Inst. for Applied Eco. Retrieved March 01, 2018, from: http://www.prosa.org/fileadmin/user_upload/pdf/leitfaden_eng_final_310507.pdf

Hallstedt, S., \& Isaksson, O. (2017). Material criticality assessment in early phases of sustainable product development. Journal of Cleaner Production, 161, 40-52. Doi: 10.1016/j.jclepro.2017.05.085

Henkel. (2014). Company Sustainability Report. Retrieved March 10, 2018, from https://www.henkel.com/blob/397758/61cefdce3aa8cbbfc9578ce9b62e7e64/data/2014sustainability-report.pdf

Hope, A. J., \& Moehler, R. (2014). Balancing Projects with Society and the Environment: A Project, Programme and Portfolio Approach. Procedia - Social and Behavioural Sciences, 119, 358-367. https://doi.org/10.1016/j.sbspro.2014.03.041

Ihuah, P. W., Kakulu, I. I., \& Eaton, D. (2014). A review of Critical Project Management Success Factors (CPMSF) for sustainable social housing in Nigeria. Int. J. of Sustainable Built Environment, 3(1), 62-71. doi:10.1016/j.ijsbe.2014.08.001

ISO (2006): 14040 Environmental management - Life cycle assessment - Principles and framework, International Organisation for Standardisation (ISO), Genève. 
Janssen, M., \& Stuart, P. (2010). Sustainable Product Portfolio and Process Design of The Forest Biorefinery. Proceedings of the Canadian Engineering Education Association. https://doi.org/10.24908/pceea.v0i0.3158

Ketola, T. (2010). Five leaps to corporate sustainability through a corporate responsibility portfolio matrix. Corporate Social Responsibility and Environmental Manag., 17(6), 320-336. https://doi.org/10.1002/csr.219

Kivilä, J., Martinsuo, M., \& Vuorinen, L. (2017). Sustainable project management through project control in infrastructure projects. Int. J. of Project Management, 35(6), 1167-1183. doi:10.1016/j.ijproman.2017.02.009

Kohl, K. (2016). Becoming a Sustainable Organization: A Project and Portfolio Management Approach (2nd ed.). Boca Raton: CRC Press.

Labuschagne, C., \& Brent, A. C. (2005). Sustainable Project Life Cycle Management: the need to integrate life cycles in the manufacturing sector. International Journal of Project Management, 23(2), 159-168. https://doi.org/10.1016/j.ijproman.2004.06.003

Lanxess. (2016). Company Report. Retrieved March 02, 2018, from https://lanxess.com/corporate/investor-relations/publications/annual-reports/

Mansoornejad, B., Chambost, V., \& Stuart, P. (2010). Integrating product portfolio design and supply chain design for the forest biorefinery. Computers and Chemical Engineering, 34, 1497-1506. https://doi.org/10.1016/j.compchemeng.2010.02.004

Marcelino-Sádaba, S., González-Jaen, L. F., \& Pérez-Ezcurdia, A. (2015). Using project management as a way to sustainability. From a comprehensive review to a framework definition. Journal of Cleaner Production, 99, 1-16. doi:10.1016/j.jclepro.2015.03.020

Martens, M., \& Carvalho, M. (2017). Key factors of sustainability in project management context: A survey exploring the project managers' perspective. International Journal of Project Management, 35(6), 1084 1102. https://doi.org/10.1016/j.ijproman.2016.04.004

Martens, M., \& Carvalho, M. (2016). The challenge of introducing sustainability into project management function: multiple-case studies. J. of Cleaner Prod., 117, 29-40. https://doi.org/10.1016/j.jclepro.2015.12.039

Meinrenken, C. J., Kaufman, S. M., Ramesh, S., \& Lackner, K. S. (2012). Fast Carbon Footprinting for Large Product Portfolios. J. of Industrial Ecology, 16(5), 669-679. https://doi.org/10.1111/j.15309290.2012.00463.x

Paris, H., Mokhtarian, H., Coatanéa, E., Museau, M. \& Ituarte, I.F. (2016). Comparative environmental impacts of additive and subtractive manufacturing technologies. CIRP Annals - Manufacturing Technology, 65(1), 29-32. Doi: 10.1007/s11663-015-0477-9

Pimentel, B. S., Gonzalez, E. S., \& Barbosa, G. N. O. (2016). Decision-support models for sustainable mining networks: fundamentals and challenges. Journal of Cleaner Production, 112, 2145-2157. https://doi.org/10.1016/j.jclepro.2015.09.023

PMI (2013). A guide to the Project Management Body of Knowledge (5th ed.). Project Management Institute.

Sánchez, M. A. (2015). Integrating sustainability issues into project management. Journal of Cleaner Production, 96, 319-330. https://doi.org/10.1016/j.jclepro.2013.12.087

Silvius, J., Kampinga, M., Paniagua, S., \& Mooi, H. (2017). Considering sustainability in project management decision making; An investigation using Q-methodology. International Journal of Project Management, 35(6), 1133-1150. https://doi.org/10.1016/j.ijproman.2017.01.011

Silvius, J., \& Schipper, R. (2015). A Conceptual Model for Exploring the Relationship Between Sustainability $\begin{array}{llll}\text { and Project Success. Procedia Computer Science, 64, 334-342 } & \end{array}$ https://doi.org/10.1016/j.procs.2015.08.497

Silvius, J., \& Schipper, R. (2014). Sustainability in Project Management Competencies: Analyzing the Competence Gap of Project Managers. Journal of Human Resource and Sustainability Studies, 02(02), 40-58. doi:10.4236/jhrss.2014.22005

Schmidt, I., Meurer, M., Saling, P., Kicherer, A., Reuter, W., \& Gensch, C. (2004). SEEbalance: Managing Sustainability of Products and Processes with the Socio-Eco-Efficiency Analysis by BASF. Greener Management International, 45, 79-94.

Solvay. (2010). Sustainable Portfolio Management guide - Solvay report. Retrieved March 01, 2018, from https://www.solvay.com/en/company/sustainability/sustainable-portfolio-

management/index.html 
Trapp, A. C., \& Sarkis, J. (2016). Identifying Robust portfolios of suppliers: A sustainability selection and development perspective. Journal of Cleaner Production, 112, 2088-2100. doi:10.1016/j.jclepro.2014.09.062 Uhlman B. \& Saling, P. (2010). Measuring and communicating sustainability through Eco-efficiency Analysis. CEP. The Global Home of Chemical Engineers AIChE. Retrieved from: http://www2.basf.us/AcrylicsDispersions/asphalt/docs/MeasuringAndCommunicatingSustainabilityT hroughEco-EfficiencyAnalysis.pdf

Ulrich, K. T., \& Eppinger, S. D. (2012). Product design and development. McGraw-Hill/Irwin.

Vandaele, N. J., \& Decouttere, C. J. (2013). Sustainable R\& D portfolio assessment. Decision Support Systems, 54(4), 1521-1532. https://doi.org/10.1016/j.dss.2012.05.054

Villamil, C., Nylander, J., Hallstedt, S., Schulte, J., \& Watz, M. (2018). Additive manufacturing from a strategic sustainability perspective. 15th International design conference, May 2018. Dubrovnik, Croatia. (Accepted).

Vliex, B. (2013). What is the role of the Project Portfolio Office in the implementation of sustainability in Project Portfolio Management (PPM)? Master thesis. University of applied sciences Utrecht. Netherlands.

Wever, R., Boks, C. B., \& Bakker, C. A. (2008). Sustainability within product portfolio management. Sustainable Innovation 08 Conference, 219-227. Retrieved from https://repository.tudelft.nl/islandora/object/uuid\%3A563ad303-48d6-4376-9973-6ed358aeccb3

Wohlin, C. (2014). Guidelines for snowballing in systematic literature studies and a replication in software engineering. Proceedings 18th Int. Conf. on Evaluation and Assessment in Software Engineering - EASE 14. doi:10.1145/2601248.2601268

World Commission on Environment and Development. (1987). Our Common Future. World Commission on Env. and Dev Report. Retrieved March 01, 2018, from http://www.un-documents.net/ourcommon-future.pdf

Zvezdov, D., \& Hack, S. (2016). Carbon footprinting of large product portfolios. Extending the use of Enterprise Resource Planning systems to carbon information management. J. of Cleaner Production, $135,1267-1275$.

Økland, A. (2015). Gap analysis for incorporating sustainability in project management. Procedia - Procedia Computer Science, 64, 103-109. https://doi.org/10.1016/j.procs.2015.08.469

Ölundh, G., \& Ritzen, S. (2004). Making an ecodesign choice in project portfolio selection. IEEE International Engineering Management Conference, 3, 913-917. https://doi.org/10.1109/IEMC.2004.1408824 